\title{
Statistical Problem Posing, Problem Refining, and Further Reflection in Grade 6
}

\author{
Jane M. Watson \& Lyn D. English
}

To cite this article: Jane M. Watson \& Lyn D. English (2017): Statistical Problem Posing, Problem Refining, and Further Reflection in Grade 6, Canadian Journal of Science, Mathematics and Technology Education, DOI: 10.1080/14926156.2017.1380867

To link to this article: http://dx.doi.org/10.1080/14926156.2017.1380867

Accepted author version posted online: 28 Sep 2017.

\section{एلll} Submit your article to this journal $\pi$

Article views: 12

a

View related articles $\sqsubset$

View Crossmark data $₫$ 


\section{Statistical Problem Posing, Problem Refining, and Further Reflection in Grade 6}

Jane M. Watson

Faculty of Education, University of Tasmania, Hobart, Australia

Lyn D. English

Faculty of Education, Queensland University of Technology, Brisbane, Australia

CONTACT Jane M. Watson, Faculty of Education, University of Tasmania, Private Bag 66, Hobart, TAS 7001, Australia

\section{Abstract}

This report is based on an activity completed by 89 Grade 6 students carrying out a statistical investigation with a focus on posing an initial question given a context and then refining it for a chosen data set. Having reached a conclusion based on evidence from their data analysis, students were given additional information on the context and asked to reconsider their conclusions and degree of certainty associated with them. Data from student workbooks were used to assess students' capacity to engage in the extensions of a statistical investigation not usually encountered at the school level. Results showed approximately $70 \%$ of students were able to carry out the complete investigation and justify a meaningful decision. 


\section{ACCEPTED MANUSCRIPT}

\section{Introduction}

As the interest in bringing statistical investigations and statistical literacy to the primary grades increases, research on children's capabilities in this field has grown. In terms of the components of a statistical investigation that support statistical literacy, Watson (2006) reported on studies related to sampling, graphing, averages, chance, beginning inference, and variation. What has received much less attention from researchers is the actual posing of the question that is the foundation of a statistical investigation. Recognising that just as professional statisticians may need to rethink and revise their questions throughout an investigation, students can be introduced to contexts with similar requirements. The study reported here was designed to reinforce Grade 6 students' ability to carry out a statistical investigation, while introducing them to the posing of meaningful questions and later to rethinking the investigation when further information is discovered.

\section{Background}

This study hence addresses three aspects of the implementation of the statistics curriculum at the school level. First is the nature of a statistical investigation appropriate for students at the school level, in this case Grade 6. Second, within the investigation there is the need for students to pose their own initial questions and then refine them. This aspect of a statistical investigation has received very little attention in the statistics education literature. Third, if more information on the context is provided, it may be necessary for students to reconsider their decisions and questions. No earlier research has been found on this aspect of a statistical investigation at the school level. These three aspects are considered in turn. 


\section{ACCEPTED MANUSCRIPT}

\section{Statistical problem solving}

The authentic introduction of statistics at the school level reflects the process that applied statisticians carry out in their profession. Wild and Pfannkuch (1999) describe this process for statisticians with the PPDAC investigative cycle, where the first $\mathrm{P}$ is for Posing a question followed by Plan, Data, Analysis, and Conclusion. Following this work at the tertiary level, the American Statistical Association released the Guidelines for Assessment and Instruction in Statistics Education (GAISE) Report (Franklin et al., 2007), turning the focus to the school level. GAISE outlines the four elements of "statistical problem solving" at the school level as (i) Formulate Question, (ii) Collect Data, (iii) Analyse Data, and (iv) Interpret Results. The Collect Data element includes "planning", and all four elements stress the omnipresence of variability, without which there would be no need for statistics (Moore, 1990).

Statistical problem solving as formulated by Wild and Pfannkuch (1999) or Franklin et al. (2007) is complemented at the school level with the idea of informal inference (Makar \& Rubin, 2009). When sampling from a population, informal inference is a generalization beyond the collected data based on the evidence from the data, acknowledging a degree of uncertainty in the conclusion reached. The recognition of uncertainty is crucial, may have several sources, and may result, for example, in repeating the PPDAC cycle. The essential contribution of context (e.g., Moore, 1990; Rao, 1975) is implicit in these descriptions of the stages of a statistical investigation and informal inference, potentially adding complexity at every stage of the PPDAC cycle. Makar, Bakker, and Ben-Zvi (2011), in discussing the role of context in informal inference, note that "[s]tudents need to learn to coordinate contextual and statistical knowledge 


\section{ACCEPTED MANUSCRIPT}

to overcome their struggle to make sense of a perceived gap between what they know from experience and what they observe in data" (p.156).

\section{Statistical problem posing}

Although it is logical that problems need to be posed before they can be solved, there has been more focus in the mathematics curriculum and the mathematics classroom on problem solving than on problem posing. In a recent effort to redress the imbalance in research, Singer, Ellerton, and Cai's (2015) book, Mathematical Problem Posing, reviews the contribution of problem posing research to mathematics education, as does Silver (2013) in a summary to a special issue of Educational Studies in Mathematics. Only one contribution to these two publications, however, looks at problem posing in the context of a statistical inquiry (English \& Watson, 2015 a). This limited interest in statistical problem posing may be a result of the difference between the relationship of a traditional mathematics problem to a unique solution and the relationship of a statistical problem to an inferential decision that has an associated uncertainty (Makar \& Rubin, 2009). Consider, however, Stoyanova and Ellerton's (1996) definition of problem posing as "the process by which, on the basis of mathematical experience, students construct personal interpretations of concrete situations and formulate them as meaningful mathematical problems" (p. 518). Replacing "mathematical" with "statistical" would appear to allow a recognition of statistical questions or hypotheses as a valid extension of research into mathematical problem posing. The "concrete situations" fit very well with "contexts", which are required as the foundation for any statistical investigation. 


\section{ACCEPTED MANUSCRIPT}

The necessity to pose questions as part of this process, has been recognized since early curriculum documents included topics related to statistics (e.g., National Council of Teachers of Mathematics [NCTM], 1989). In its later Principles and Standards for School Mathematics for Data Analysis and Probability, the NCTM (2000) lists as its first standard for all levels from prekindergarten to Grade 12, "Formulate questions that can be addressed with data, and collect, organize, and display relevant data to answer them" (p. 48). More recently, one of the aims of the Australian Curriculum: Mathematics (Australian Curriculum, Assessment and Reporting Authority [ACARA], 2016) includes "pose and solve problems and reason in ... statistics and probability” (p. 4). Specifically for Grade 5, the Proficiency Strand Reasoning includes “... posing appropriate questions for data investigations and interpreting data sets" (p. 17).

Arnold (2008) suggested two types of involvement in statistical problem posing, one being to set the overall problem for investigation and the other being to devise survey questions to address a larger research question. Most studies in this area have followed the line of devising survey questions, with Lavigne and Lajoie (2007) conducting case studies of two groups of three Grade 7 students and Meletiou-Mavrotheris and Paparistodemou (2015) considering a Grade 6 class using their survey questions to explore community service in their school. English and Watson (2015 a) had students create survey questions for their class mates to answer in order to make suggestions for improvement to the school playground. Watson and English (2015) combined the two approaches, using survey questions from the Australian Bureau of Statistics (ABS) CensusAtSchool site ( $<$ http://www.abs.gov.au/censusatschool $>)$ rather than devised by students, to consider whether Grade 5 students were environmentally friendly. In using the ABS set of questions, each student decided the criteria, for example the percentage of "yes" responses, 


\section{ACCEPTED MANUSCRIPT}

required in order to convince him/her that a sample was environmentally friendly. The current study follows the first path of devising the overall question, as done by Allmond and Makar (2010) in a study with 9-year-old students. Allmond and Makar piloted eight lessons over a month focussing on characteristics of investigative questions, envisaging related data, refining questions, and considering the purpose of the solutions to their questions. Using pre- and posttests, they categorised students' questions posed in a seven-stage hierarchy that included irrelevant, closed, and inquiry questions, finding a significant positive difference for those who had experienced the lessons compared with other classes that had not.

\section{Further reflection on a problem}

The influence of context and its possible change throughout an investigation add to the variability experienced and at times require students to rethink their conclusions and perhaps their questions. In this study, it is extra and unanticipated new information on the context that forces students to reconsider their questions and decisions. Konold and Higgins (2003) use the term backtracking to refer to the experience when "researchers look backward ... and their questions often evolve and change as they discover unanticipated results in the data" (p. 194). The idea of introducing additional information encouraging reflection on a decision about a question also reflects the "what-if-not" approach of Brown and Walter (1983) in suggesting the exploration of the consequences of accepting rather than negating the conclusion for the question posed. Further the advice of Polya (1957) in relation to "how to solve" problems, involves "looking back," which in turn consolidates understanding and generates new ideas. 


\section{ACCEPTED MANUSCRIPT}

\section{Theoretical framework for analysis}

Learning in the classroom is meant to build on previous knowledge to reach higher, more complex cognitive levels. Evolving from the work of Piaget (1952), Biggs and Collis (1982, 1991) developed the Structure of the Observed Learning Outcome (SOLO) taxonomy to evaluate the quality of learning (Pegg, 2003). The SOLO model covers five modes of development from Sensorimotor (from birth) to PostFormal (from about 20 years), with the third mode, Concrete Symbolic (from around 6 to 14 years), being the years of primary and middle school - the mode of interest in this study. Within each mode a hierarchical learning cycle is based on the structure observed in a response to a task employing the elements available to accomplish the task. Three of the hierarchical levels are relevant to the current study:

(i) Unistructural (Uni), where responses employ single elements, sometimes creating unacknowledged contradictions;

(ii) Multistructural (Multi), where responses employ multiple elements, usually in sequence, sometimes recognizing but not resolving conflicts among the elements;

(iii) Relational (Rel), where responses relate elements and create closure for the task.

The SOLO model has been employed across many areas of mathematics and statistics education over the years, either as the main vehicle to assess learning (e.g., Jones, Langrall, Mooney, \& Thornton, 2004; Pegg, 2003; Reading \& Reid, 2006). It has also been adapted for teachers' use in the classroom as a model for learning (e.g., Hook, 2015; Hook, Garrett, Howard, \& John, 2014). In this study, although aware of the aims of the SOLO hierarchy generally in the classroom, the teachers involved were not asked specifically to use it in planning. In the larger study including the activity described here, the SOLO model has been used in assessing student capability in relation to variation in measurement (English \& 


\section{ACCEPTED MANUSCRIPT}

Watson, 2015b), probabilistic understanding (English \& Watson, 2016), and exploring typical reaction time (Watson \& English, 2017).

\section{Research question}

The research interest in this study is the students' capacities to employ their developing understanding of statistical problem solving (Franklin, et al., 2007) with the added complexities of posing meaningful questions in a context and revisiting their decisions when given extra information. The overall research question hence is the following.

Give a general context for carrying out a statistical investigation, what is the capacity shown by students to

(i) pose an initial meaningful statistical question,

(ii) refine the question for a chosen data set and sketch an initial representation,

(iii) create a representation in TinkerPlots to complete the analysis and reach a conclusion stating a degree of uncertainty, and

(iv) reflect on the decision given further information on the context?

\section{Methodology}

\section{Background and design}

The activity reported here is the initial part of the seventh activity in a longitudinal 3-year project introducing statistical problem solving and informal inference as a foundation for statistical literacy in Grades 4 to 6 . The previous activities beginning in Grade 4, included (i) the introductory one on problem posing through developing surveys (English \& Watson, 2015 a); (ii) a measurement activity to introduce different types of variation (English \& Watson, 2015b); (iii) modelling the probability of outcomes from tossing two coins (English \& Watson, 2016); (iv) 


\section{ACCEPTED MANUSCRIPT}

introducing the steps of a statistical investigation by exploring the question of Grade 5 students being environmentally friendly (Watson \& English, 2015); (v) trialling different methods of collecting data to determine the typical reaction time of Grade 5 students (Watson \& English, 2017); and (vi) using eye colour as a basis for comparing the reaction time for two groups of Grade 6 students (Watson \& English, in press). Within the activities and across the project, the design-based research format of Cobb, Confrey, diSessa, Lehrer, and Schauble (2003) was used including the design and preparation of materials, the carrying out of the teaching activity with data collection, and the retrospective analyses influencing the next activity. Each activity was introduced to the teachers in a professional learning session including a detailed lesson plan printed in parallel with the student workbook. Teachers delivered the activity in their individual classrooms. All activities except the first made use of the software TinkerPlots: Dynamic Data Exploration (Konold \& Miller, 2011). The software was developed Grade 4 and beyond. Students are presented with data as a "stack" of data cards (e.g., see Figure 2) and can design their own plots by ordering, stacking, and separating data icons, transforming one display into another, using drag-and-drop features. Examples of plots created in earlier activities by the students in this study are shown in Figure 1.

\section{Participants}

The participants were 89 Grade 6 students (mean age 11 years, 10 months) in four classes at a government-run school in an Australian capital city. Most of the students had been involved with the researchers for the previous $2 \frac{1}{2}$ years and interacted with them freely in the classroom, both asking and answering questions. Only data from students whose parents gave written permission are reported; however, all students in the classes took part in the activity. Gender was evenly 


\section{ACCEPTED MANUSCRIPT}

split with 45 girls and 44 boys. Forty-three percent of the students (38) were classified as having English as a second language (ESL). Pseudonyms are used throughout when referring to students.

\section{Procedure}

The activity reported here was the first part of an all-day intervention in each classroom. After considering the question of athletes improving over time as described below, students later selected their own Australian swimming teams for the 2016 Olympics (reported elsewhere, English \& Watson, 2017). The first part took approximately $2 \frac{1}{2}$ to 3 hours, depending on the class.

The lesson began with a review of the terms students had been using in previous activities to describe middles of data: mode, median, mean, and hat plot. Students were then asked to recall "things to consider" when looking at data and a list was written on the whiteboard to be referenced during the activity. The list included overall shape, end points, scale, range, outliers, clusters, and gaps. Finally referring to a poster on the wall and used in the previous three activities, the teacher had the students recall and describe the "4 steps to making a decision with data": Pose Question, Collect Data, Analyse Data, and Make Decision, reflecting the GAISE Report (Franklin, 2007).

The students next watched a video clip of Usain Bolt running in the London 2012 Olympics 100 m Final (http://www.youtube.com/watch?v = lacjJVxC5d0;3.38mins). Bolt set an Olympic record of 9.63 seconds, having also set a record of 9.69 seconds at the 2008 Beijing Olympics. Following a brief class discussion on the records displayed in the video clip, the teachers invited the students to think about the question, "Are athletes getting better over time?" The question 


\section{ACCEPTED MANUSCRIPT}

was deliberately vague so that students could experience the importance of refining questions in order to answer them statistically and meaningfully.

Working in small groups, the students first informally discussed their views on the question. Shane's group commented, "It's too broad... you can't answer that question," while Monika's group thought there were lots of "assumptions" in the question:

Monika: Because you could be like [an] Olympic and train a lot...?

Kelly: Yeah, because when you think about it, um, like as you get older, you're going to get like slower.

Monika: You're going to get stronger and you're going to get more stamina but like are you actually like going to improve...

Kelly: So it, it really, it really has to depend...

Monika: Yeah, like that's a really big like assumption to like say that all athletes get better.

A class discussion followed in which students questioned the vagueness of the terms, "athletes", "getting better", and "over time". They also considered how "better" and "over time" might be measured. Such measurements and their units vary across different sporting events, with some being more complex to determine than others (e.g., in gymnastics and diving). These comments helped to set the scene and motivate students for the main part of the activity.

After the initial discussion, students were asked to write in their workbooks a question that would be more appropriate to consider whether athletes were getting better over time. To assist in thinking about the implications of their questions, students were also asked to indicate what data they would collect to answer their questions. Another discussion followed with students critiquing each other's questions and pointing out difficulties with actually finding the required data. Given the time constraints of the research, the age of the students, and the general context 


\section{ACCEPTED MANUSCRIPT}

of the introduction with the video of Usain Bolt, students working in pairs were given data sets for 12 Olympic events including $100 \mathrm{~m}$ sprint, $1500 \mathrm{~m}$ running, high jump, and long jump, and two freestyle swimming events. For each event there were both men's and women's data since the beginning of the event. An example data set is shown in Appendix A. After pairs of students chose one of the 12 data sets, students individually wrote a revised question for that data set in their workbooks, indicated which data they would use, and created a hand-drawn sketch in their workbooks to show how they would analyze the data to reach a decision on athletes' improvement. The purpose of the sketch was to orient students to thinking about time series as a way to tell the story within the data, an approach they had not encountered before.

Students then were given the TinkerPlots file for their chosen event and worked in pairs on laptop computers to continue their analysis from representations that they created in the software. Students then answered a series of questions on their use of the TinkerPlots representation to come to a conclusion and their certainty about the decision. After the students created their first plots in TinkerPlots, there was a class discussion of the possibility to use trend lines to summarise the movement in the data over time. Students were shown how to use the Draw tool in TinkerPlots to draw a trend line and asked to draw one on a second plot (saved separately). Some students wrote about their trend lines in Text boxes in the TinkerPlots file.

Finally, to reinforce the real-world nature of statistical analyses, students were shown a PowerPoint presentation of a TED talk < http://tedsummaries.com/2014/05/03/david-epstein-areathletes-really-getting-faster-better-stronger/ > describing how advances in technology have contributed to athletes' improved performances. Subsequently, the students were to backtrack and reflect on their prior conclusions and the certainty of their recorded decisions, indicating 


\section{ACCEPTED MANUSCRIPT}

whether they regarded these as still justifiable. The workbook questions used for this analysis are found in Table 1 and are directly linked to the four parts of the Research Question. Each question in the workbook had a visual "staircase" icon numbered by the step of a statistical investigation associated with the task.

\section{Analysis}

The source of data to address the research question was the students' responses written in the workbooks and the TinkerPlots files created for the data set chosen by each pair of students. The specific responses for analysis were chosen from four parts of the workbooks as seen in Table 1: (i) two responses about the initial question posed, (ii) three on refining the question for a chosen Olympic data set, (iii) three on the analysis using TinkerPlots, and (iv) two after being shown the information on technological changes potentially affecting results.

The assessment of the responses in the workbooks was based on the SOLO model (Biggs \& Collis, 1982, 1991; Pegg, 2003). The SOLO model is appropriate for the research question in this study, first, because the judgment of capacity can be based on the cognitive complexity of the responses provided, and second, because the model is based on the "observed" responses written in the workbook rather than speculation of what the students might have meant to write or have said in class discussion. The model is used to assess response complexity by considering how the fundamental elements provided in the context for the investigation are combined to provide an answer to a particular task. In this study, the elements vary for each part of the activity. In Part (i), they are very general: "athletes", “improvement", “event”, "time”, and “data". For Part (ii), they are the chosen data set, added to the elements for Part (i), along with "graph". In Part (iii), the TinkerPlots file with data is added but otherwise it is how the other elements are combined 


\section{ACCEPTED MANUSCRIPT}

with the new graph to make a decision that is assessed. Similarly for Part (iv), the only additional element is the information on technological advances. As applied here for students who had had experience with statistical investigations as summarised earlier, the relevant levels within the Concrete Symbolic mode, the mode of development appropriate for Grade 6, are (i) Unistructural (Uni), where students use the elements of statistics and/or context in a singular fashion; (ii) Multistructural (Multi), where students use several elements in a sequential fashion; and (iii) Relational (Rel), where students show evidence of interrelating elements in a meaningful way in the conclusion reached.

The rubrics for the individual questions (see Appendix B) reflected the SOLO model, were created by the first author, and were revised in consultation with an experienced research assistant who completed the coding; coding was subsequently checked by the author. Because each pair of students had potentially different data sets after Part (i), coding took place across all responses for each student rather than across all students for each question. Previous responses were taken into account in some cases. Subsequently codes for the individual questions were summed for each part of the research question. The final SOLO level for each part of the activity

in Table 2 was then based on a consideration of the elements used across the two or three questions, and hence there are alternative ways of achieving most levels. For all four parts of the workbook it was necessary to achieve a Relational response on at least one question in that part in order to be classified as Relational for that part. Most Multistructural responses for parts of the workbook were evident on individual questions in those parts but a few were shown across two. Examples are provided in the Results. 


\section{ACCEPTED MANUSCRIPT}

\section{Results}

Percentages of responses and examples for each part of the activity are presented in relation to the Research Question.

\section{Part (i): Posing an initial question}

Table 3 shows two pairs of responses for each level in Part (i) of the activity, along with the percentage of responses at the levels. The answers to the two questions were from the same student each time (IDs shown), with the responses considered together to determine the overall level as detailed in Table 2. The two questions in Part (i) were about posing the initial question and suggesting the data that would be needed to be collected to answer it. At each higher level, more specificity was included in choosing specific, relevant elements to set the scene for a realistic investigation, for example, the event, the athletes, the time span, and the source of data. After filling in responses in their workbooks, students engaged in a sharing time where the teacher and other students critiqued the questions posed and data suggested. As seen in Table 3, more than a third of responses showed difficulty in focussing on the need for specificity. At times students raised questions about how they were going to find the data, e.g., "we need the names and the times from all of the races" or "it depends on how much information we find."

\section{Part (ii): Refining question for Olympics, choosing data, and sketching a representation}

Next, teachers introduced the students to the 12 Olympic data sets from which pairs could choose one to focus their further refinement of the question on athletes getting better over time.

Because of the lack of experience of the students with time-series graphs, the teachers made informal suggestions about how students could keep track of the time over which athletes may have improved. Table 4 shows two sets of responses for the three questions in Part (ii) of the 


\section{ACCEPTED MANUSCRIPT}

activity at each SOLO level, as well as the percentage of responses at each level. Forty-five percent of responses at the Relational level related the elements of the refined question, data, and a plot meaningfully, culminating in a sketch that proposed an authentic representation. At the Multistructural level, $36 \%$ of responses basically stated the elements required for the question and data but could not combine them for a meaningful representation. At the Unistructural level $16 \%$ of responses indicated single elements for each question but did not combine them meaningfully in a graph.

\section{Part (iii): Analysis using TinkerPlots file}

Because of the details involved in the data and the students' previous experience with TinkerPlots, students were then given files with the data from their chosen events. The data were presented as Data Cards, with students given freedom to create plots as they desired. An example of the Data Card presentation for the Men's Long Jump data in Appendix A is shown in Figure 2. Examples of the TinkerPlots plots created by students are displayed with the other responses in Table 5.

Table 5 shows two sets of responses at each SOLO level for the three questions in Part (iii) of the activity and the percentages of responses at these levels. As seen in Table 5, most responses included creation of meaningful plots in TinkerPlots, although the level of use of the plots to make decisions varied. Nearly half $(47 \%)$ successfully related the elements across the three questions and their graphs to a specific decision with evidence supporting their degree of certainty at the Relational level. About a third of responses (34\%) selected several relevant elements but were not convincing in combining them and justifying certainty (Multistructural). Finally, 19\% of responses included single isolated or repeated statements across the questions. 


\section{ACCEPTED MANUSCRIPT}

\section{Part (iv): Reflecting on further information}

Table 6 shows two sets of responses at each SOLO level for the two questions in Part (iv) of the activity and the percentages of responses at the levels. Seven students (8\%) did not engage with the further information from the TED report. Despite only three responses reaching the highest code (3) on both questions, all Relational responses for Part (iv) included conditional reasoning for at least one of the questions. Although not all responses provided Relational reasoning, $70 \%$ acknowledged uncertainty about their results given the additional information. At the Multistructural level, responses included several elements containing relevant evidence for uncertainty without further integrated reflection. Unistructural responses acknowledged single pieces of evidence without uncertainty.

\section{Summary}

Table 7 summarises the levels of responses across the four parts of the activity. Because the SOLO model is based on observed learning outcomes it is not possible to speculate on what responses students may have provided in different circumstances, perhaps with more prompting. Observation of the research team in the classroom was that in Part (i) some students did not appreciate the seriousness of posing questions and did not progress past more superficial responses; this is reflected in the $38 \%$ of Unistructural responses to Part (i). For Part (ii), having specific data sets with which to work helped students recognise elements that could be incorporated in their questions and proposed analyses. This resulted in increased levels of performance for many students. This continued into Part (iii) when TinkerPlots assisted students as they created plots for their data sets and used their previous experience with the software to create meaningful representations. Part (iv) illustrated students' willingness to be challenged 


\section{ACCEPTED MANUSCRIPT}

about their conclusions, but lack of experience in arguing strongly, shown in more Multistructural than Relational responses. The $22 \%$ of Unistructural responses illustrated the inability to incorporate the additional information and review the certainty of their decisions from Part (iii).

Figure 3 shows the distribution of the Overall Total coding scores for the activity. The middle of the data bounded by the box plot includes $66 \%$ of the data. This is suggesting that these Grade 6 students have a fairly strong overall Multistructural capacity to consider this activity, with 15\% consistently able to work at a Relational level, and about 19\% struggling to combine the elements of the practice of statistics in more than a singular fashion. Gender did not play a role in the outcomes with only a slightly higher mean for girls and a few more boys in the Unistructural group. ESL status did not have a negative impact, with ESL students having a slightly higher mean than other students with fewer students in the Unistructural group and more in the Relational group.

\section{Discussion}

The contribution of this study is considered from several perspectives, including the importance of carrying out complete statistical investigations in elementary school with a focus on problem posing and of using a developmental framework for assessing student capacity. There are also implications for teaching strategies in the classroom and further research, as well as enhancing statistical literacy more generally.

In relation to the PPDAC investigative cycle used by applied statisticians (Wild \& Pfannkuch, 1999), this study reinforces the view of the GAISE Report (Franklin et al., 2007) that it is both feasible and important to introduce such a practice at the school level. Anecdotally, the students 


\section{ACCEPTED MANUSCRIPT}

were highly motivated by the activity, as illustrated in the classroom discussion that took place and in the oral reports presented by the students (English, 2015). As the first half of the culminating activity for the larger project of which it was a part, the investigation carried out by the students reinforced their previous experiences of carrying out complete statistical investigations (e.g., Watson \& English, 2015, 2017).

More specifically, in relation to problem posing, although mathematics curriculum documents (e.g., ACARA, 2016; NCTM, 2000) include problem posing specifically in association with statistical inquiry, very little research has taken place in this realm. That which has occurred has been in contexts where a general question moves quickly into the construction of survey questions from which data can be collected from other students in the class (e.g., Lavigne \& Lajoie,2007; Meletiou-Mavrotheris \& Paparistodemou, 2015). Compared to the study of Allmond and Makar (2010) with slightly younger students, which considered students setting the overall question for investigation, it was not possible to identify seven levels of the initial problem posing in this study. It is likely that providing the Olympic data sets in this study, avoided the focus on irrelevant and closed questions; also, Allmond and Makar did not add extra information to the contexts for their students. It is disappointing to find that the US Common Core State Standards for Mathematics (Common Core State Standards Initiative, 2010) not only omits Statistics and Probability until Grade 6, but also makes no mention of statistical problem posing. Although the students in this study did not have the further opportunity to re-pose their questions, as Konold and Higgins (2003) suggested often happens for adult researchers when they backtrack, students were asked to rethink the confidence they had in the conclusions reached. In encouraging students to at least rethink the conclusions and questions posed in the 


\section{ACCEPTED MANUSCRIPT}

light of further information, the activity asked students to follow Polya's (1957) advice to "look back" after reaching a decision on a question, consolidating initial understanding, and to explore the related concepts more fully, further acknowledging the possibility to pose more questions (Brown \& Walter, 1983).

The results of analysing students' responses in their workbooks as they completed the four parts of the Athletes activity indicated that approximately $70 \%$ of the Grade 6 students in this study could engage meaningfully with a statistical investigation that involved revising a question, carrying out analysis of data, reaching a conclusion, and rethinking the conclusion based on additional information about the context. Based on the SOLO cognitive model (Biggs \& Collis, 1982, 1991; Pegg, 2003) these students could create arguments in a sequential manner using the elements available to them to refine their initial questions, make decisions based on analysing their representations, and reflect on their conclusions based on additional information. Some students could go further and produce more complex, integrated arguments combining the elements. This study adds to previous research in statistics education at the school level using the SOLO model (e.g., Groth, 2003; Reading \& Reid, 2006; Watson, 2006; Watson \& English, 2015), suggesting it is reasonable to describe the capacity of students to engage in statistical investigations developmentally. Given the complexity of the activity, not previously known to be carried out with Grade 6 students, this research provides benchmarks for further research. As well as using the SOLO model to assess student outcomes as done in this study, the work of Hook (2015) provides practical suggestions for teachers to use SOLO in the classroom, both to make learning visible for the students and to plan specific strategies for moving students' thinking to higher levels. This work provides an opportunity for further research. Combined with 


\section{ACCEPTED MANUSCRIPT}

the use of authentic contexts, Hook's work should also encourage classroom teachers to move beyond a procedural approach to the statistics curriculum.

This activity was part of the final investigation of a 3-year study exploring the potential to build statistical literacy understanding in upper primary students through experiences grounded in statistical problem solving (Franklin et al., 2007) and informal inference (Makar \& Rubin, 2009). Although much has been written about statistical literacy for adults (e.g., Gal, 2002; Wallman, 1993), at the school level, Watson (2006) provides a concise description.

Statistical literacy is the meeting point of the data and chance curriculum and the everyday world, where encounters involve unrehearsed contexts and spontaneous decision-making based on the ability to apply statistical tools, general contextual knowledge, and critical literacy skills. (Watson, 2006, p.11)

In the activity described here students encountered an unrehearsed context where they had not only to make decisions but also to reconsider their decisions. To do this they had to use their contextual knowledge of athletes and the Olympics, apply the statistical tools they had been developing over the three years of the project, and use their critical literary skills to interpret the further information provided to rethink their positions on the questions they had posed. Outside of school, they will meet situations where they need to think critically about questions posed in order to judge the conclusions claimed by the poser. Hopefully the experience gained in this and previous activities will stand them in good stead in these situations.

\section{Acknowledgements}

This study was funded by Australian Research Council project number DP120100158. Any opinions, findings, and conclusions or recommendations expressed are those of the authors and 


\section{ACCEPTED MANUSCRIPT}

do not necessarily reflect the views of the ARC. We wish to acknowledge the excellent support of our senior research assistants, Jo Macri, who organised all materials and setup for the classrooms, and Dr Ben Kelly, who assisted with the coding. 


\section{ACCEPTED MANUSCRIPT}

\section{References}

Allmond, S., \& Makar, K. (2010). Developing primary students' ability to pose questions in statistical investigations. In C. Reading (Ed.), Data and context in statistics education: Towards an evidence-based society (Proceedings of the 8th International Conference on the Teaching of Statistics, Ljubljana, Slovenia, July 11--16). Voorburg, The Netherlands: International Statistical Institute. Retrieved from http://iaseweb.org/documents/papers/icots8/ICOTS8_8A1_ALLMOND.pdf

Arnold, P. (2008). What about the P in the PPDAC cycle? An initial look at posing questions for statistical investigation. Proceedings of the 11th International Congress of Mathematics

Education, Monterrey, Mexico, 6--13 July, 2008. Retrieved from http://tsg.icme11,org/tsg/show/15

Australian Curriculum, Assessment and Reporting Authority. (2013). General capabilities in the Australian Curriculum, January, 2013 (updated September 2014). Sydney, NSW: ACARA.

Biggs, J.B., \& Collis, K.F. (1982). Evaluating the quality of learning: The SOLO taxonomy. New York: Academic Press.

Biggs, J.B., \& Collis, K.F. (1991). Multimodal learning and the quality of intelligent behaviour. In H.A.H. Rowe (Ed.), Intelligence: Reconceptualization and measurement (pp. 57--76). Hillsdale, NJ: Lawrence Erlbaum.

Brown, S.I., \& Walter, M.I. (1983). The art of problem posing. Philadelphia, PA: Franklin Institute Press.

Cobb, P., Confrey, J., diSessa, A., Lehrer, R., \& Schauble, L. (2003). Design experiments in 


\section{ACCEPTED MANUSCRIPT}

Common Core State Standards Initiative. (2010). Common Core State Standards for Mathematics. Washington, DC: National Governors Association for Best Practices and the Council of Chief State School Officers. Retrieved from http://www.corestandards.org/assets/CCSSI_Math\%20Standards.pdf

English, L.D. (2015). STEM: Challenges and opportunities for mathematics education. In K. Beswick, T. Muir, \& J. Wells (Eds.), Climbing mountains, building bridges (Proceedings of $39^{\text {th }}$ conference of the International Group for the Psychology of Mathematics Education, Hobart, Tasmania, 13--18 July, Vol. 1., pp. 3--18). Hobart: PME.

English, L.D., \& Watson, J.M. (2015 a). Statistical literacy in the elementary school: Opportunities for problem posing. In F. Singer, N. Ellerton, \& J. Cai (Eds.), Problem posing: From research to effective practice (pp. 241--256). Dordrecht: Springer. [ISBN 978-1-46146257-6] DOI 10.1007/978-1-4614-6258-3

English, L., \& Watson, J. (2015b). Exploring variation in measurement as a foundation for statistical thinking in the elementary school. International Journal of STEM Education, 2(3). DOI 10.1186/s40594-015-0016-x

English, L., \& Watson, J. (2016). Development of probabilistic understanding in fourth grade. Journal for Research in Mathematics Education, 47, 28--62.

English, L., \& Watson, J. (2017). Developing sixth-grade students' statistical literacy through modeling with data. Manuscript submitted for publication.

Franklin, C., Kader, G., Mewborn, D., Moreno, J., Peck, R., Perry, M., \& Scheaffer, R. (2007). Guidelines for assessment and instruction in statistics education (GAISE) report: A preK-12 


\section{ACCEPTED MANUSCRIPT}

curriculum framework. Alexandria, VA: American Statistical Association. Retrieved from http://www.amstat.org/education/gaise/

Gal, I. (2002). Adults' statistical literacy: Meanings, components, responsibilities. International Statistical Review, 70, 1--51.

Groth, R. (2003). High school students' levels of thinking in regard to statistical study design. Mathematics Education Research Journal, 15(3), 252--269.

Hook, P. (2015). First steps with SOLO Taxonomy: Applying the model in your classroom. Laughton, UK: Essential Resources Educational Publishers Limited.

Hook, P., Garrett, C., Howard, M., \& John, E. (2014). SOLO Taxonomy in mathematics: Strategies for thinking like a mathematician. Invercargill, NZ: Essential Resources Educational Publishers Limited.

Jones, G.A., Langrall, C.W., Mooney, E.S., Thornton, C.A. (2004). Models of development in statistical reasoning. In D. Ben-Zvi \& J. Garfield (Eds.), The challenge of developing statistical literacy, reasoning and thinking (pp. 97--117). Dordrecht, The Netherlands: Kluwer.

Konold, C., \& Higgins, T.L. (2003). Reasoning about data. In J. Kilpatrick, W.G. Martin, \& D. Schifter, (Eds.), A research companion to Principles and Standards for School Mathematics (pp. 193--215). Reston, VA: National Council of Teachers of Mathematics.

Konold, C., \& Miller, C.D. (2011). TinkerPlots: Dynamic data exploration [Computer software, Version 2.2]. Emeryville, CA: Key Curriculum Press.

Lavigne, N.C., \& Lajoie, S.P. (2007). Statistical reasoning of middle school children engaging in survey inquiry. Contemporary Educational Psychology, 32(4), 630--666. 


\section{ACCEPTED MANUSCRIPT}

Makar, K., Bakker, A., \& Ben-Zvi, D. (2011). The reasoning behind informal statistical inference. Mathematical Thinking and Learning, 13, 152--173.

Makar, K., \& Rubin, A. (2009). A framework for thinking about informal statistical inference. Statistics Education Research Journal, 8(1), 82--105. Retrieved from http://iaseweb.org/documents/SERJ/SERJ8(1)_Makar_Rubin.pdf

Meletiou-Mavrotheris, M., \& Paparistodemou, E. (2015). Developing students' reasoning about samples and sampling in the context of informal inferences. Educational Studies in Mathematics, 88, 385--404.

Moore, D.S. (1990). Uncertainty. In L.A. Steen (Ed.), On the shoulders of giants: New approaches to numeracy (pp. 95--137). Washington, DC: National Academy Press.

National Council of Teachers of Mathematics. (1989). Curriculum and evaluation standards for school mathematics. Reston, VA: Author.

National Council of Teachers of Mathematics. (2000). Principles and standards for school mathematics. Reston, VA: Author.

Pegg, J.E. (2003). Assessment in mathematics: A developmental approach. In J.M. Royer (Ed.), Mathematical cognition (pp. 227--259). Greenwich, CT: Information Age Publishing.

Piaget, J. (1952). The origin of intelligence in children. New York: International University Press, Inc.

Polya, G. (1957). How to solve it: A new aspect of mathematical method (2 ${ }^{\text {nd }}$ ed.). Garden City, NY: Doubleday.

Rao, C.R. (1975). Teaching of statistics at the secondary level: An interdisciplinary approach. International Journal of Mathematical Education in Science and Technology, 6, 151--162. 


\section{ACCEPTED MANUSCRIPT}

Reading, C., \& Reid, J. (2006). An emerging hierarchy of reasoning about distribution: From a variation perspective. Statistics Education Research Journal, 5(2), 46--68. Retrieved from https://iase-web.org/documents/SERJ/SERJ5(2)_Reading_Reid.pdf

Silver, E.A. (2013). Problem-posing research in mathematics education: Looking back, looking around, looking ahead. Educational Studies in Mathematics, 83, 157--162.

Singer, F., Ellerton, N., \& Cai, J. (Eds.). (2015). Problem posing: From research to effective practice. Dordrecht: Springer.

Stoyanova, E., \& Ellerton, N.F. (1996). A framework for research into students' problem posing in school mathematics. In P.C. Clarkson (Ed.), Technology in mathematics education (pp. 518-525). Melbourne: Mathematics Education Research Group of Australasia and University of Melbourne.

Wallman, K.K. (1993). Enhancing statistical literacy: Enriching our society. Journal of the American Statistical Association, 88, No. 421, 1--8.

Watson, J.M. (2006). Statistical literacy at school: Growth and goals. Mahwah, NJ: Lawrence Erlbaum.

Watson, J., \& English, L. (2013). Data and measurement in year 4 of the Australian Curriculum: Mathematics. In S. Herbert, J. Tillyer, \& T. Spencer (Eds.), Mathematics: Launching futures (Proceedings of the $24^{\text {th }}$ biennial conference of the Australian Association of Mathematics Teachers, Inc., pp. 157--165). Adelaide: AAMT, Inc.

Watson, J., \& English, L. (2015). Introducing the practice of statistics: Are we environmentally friendly? Mathematics Education Research Journal, 27, 585--613. DOI 10.1007/s13394-0150153-z 


\section{ACCEPTED MANUSCRIPT}

Watson, J., \& English, L. (2017). Reaction time in Grade 5: Data collection within the Practice of Statistics. Statistics Education Research Journal, 16(1), 262--293. Retrieved from https://iase-web.org/documents/SERJ/SERJ16(1)_Watson.pdf

Watson, J., \& English, L. (in press). Eye color and the practice of statistics in grade 6: Comparing two groups. Journal of Mathematical Behavior.

Wild, C., \& Pfannkuch, M. (1999). Statistical thinking in empirical enquiry. International Statistical Review, 67(3), 223--248. 


\section{Appendix A - Example Data Set}

Men's Long Jump Olympic Games Gold Medal Results

\begin{tabular}{|c|c|c|c|c|c|}
\hline City & Year & Result (m) & Age & Name & Country \\
\hline Athens & 1896 & 6.35 & 22 & Ellery Clark & USA \\
\hline Paris & 1900 & 7.185 & 23 & Alvin Kraenzlein & USA \\
\hline St Louis & 1904 & 7.34 & 24 & Meyer Prinstein & USA \\
\hline London & 1908 & 7.48 & 22 & Frank Irons & USA \\
\hline Stockholm & 1912 & 7.60 & 24 & Albert Gutterson & USA \\
\hline Antwerp & 1920 & 7.15 & 24 & William Petersson & SWE \\
\hline Paris & 1924 & 7.445 & 20 & William De Hart Hubbard & USA \\
\hline Amsterdam & 1928 & 7.73 & 22 & Edward Barton Hamm & USA \\
\hline Los Angeles & 1932 & 7.64 & 26 & Edward Lansing Gordon & USA \\
\hline Berlin & 1936 & 8.06 & 22 & Jesse Owens & USA \\
\hline London & 1948 & 7.825 & 25 & William Steele & USA \\
\hline Helsinki & 1952 & 7.57 & 24 & Jerome Biffle & USA \\
\hline Melbourne & 1956 & 7.83 & 26 & Gregory Curtis Bell & USA \\
\hline Rome & 1960 & 8.12 & 21 & Ralph Boston & USA \\
\hline Tokyo & 1964 & 8.07 & 22 & Lynn Davies & GBR \\
\hline Mexico & 1968 & 8.90 & 22 & Bob Beamon & USA \\
\hline Munich & 1972 & 8.24 & 19 & Randel Williams & USA \\
\hline Montreal & 1976 & 8.35 & 28 & Arnie Robinson & USA \\
\hline Moscow & 1980 & 8.54 & 21 & Lutz Dombrowski & GER \\
\hline Los Angeles & 1984 & 8.54 & 23 & Carl Lewis & USA \\
\hline Seoul & 1988 & 8.72 & 27 & Carl Lewis & USA \\
\hline Barcelona & 1992 & 8.67 & 31 & Carl Lewis & USA \\
\hline Atlanta & 1996 & 8.50 & 35 & Carl Lewis & USA \\
\hline
\end{tabular}




\section{ACCEPTED MANUSCRIPT}

\begin{tabular}{|l|l|l|l|l|l|}
\hline Sydney & 2000 & 8.55 & 27 & Ivan Pedroso & CUB \\
\hline Athens & 2004 & 8.59 & 26 & Dwight Phillips & USA \\
\hline Beijing & 2008 & 8.34 & 25 & Irving Saladino & PAN \\
\hline London & 2012 & 8.31 & 26 & Greg Rutherford & GBR \\
\hline
\end{tabular}




\section{Appendix B}

\section{Athletes Workbook Questions and Rubrics}

\begin{tabular}{|c|c|c|}
\hline Question & Code & Description response \\
\hline Part (i) & 0 & No response; not a question \\
\hline \multirow[t]{2}{*}{ 1. Pose a question } & 1 & $\begin{array}{l}\text { General question on "athletes" or "getting } \\
\text { better" }\end{array}$ \\
\hline & 2 & $\begin{array}{l}\text { Question based on a specific sport, type of } \\
\text { improvement and time frame. }\end{array}$ \\
\hline Part (i) & 0 & No response; data not related to question \\
\hline 2. Collect data & 1 & $\begin{array}{l}\text { One of data set, measurement or time } \\
\text { related to question }\end{array}$ \\
\hline \multirow[t]{2}{*}{$\begin{array}{l}\text { What data would you need to } \\
\text { answer your question? }\end{array}$} & 2 & $\begin{array}{l}\text { Two of data set, measurement or time } \\
\text { related to question }\end{array}$ \\
\hline & 3 & $\begin{array}{l}\text { Names data set and measurement over time } \\
\text { period - related to question }\end{array}$ \\
\hline Part (ii) & 0 & $\begin{array}{l}\text { No response or general question on } \\
\text { "athletes" or "getting better" }\end{array}$ \\
\hline \multirow[t]{2}{*}{ 1. Refined/group question } & 1 & $\begin{array}{l}\text { Specific question including one or two of: } \\
\text { specific sport, type of improvement, or } \\
\text { time frame }\end{array}$ \\
\hline & 2 & $\begin{array}{l}\text { Specific question including all three of: } \\
\text { specific sport, type of improvement, and } \\
\text { time frame }\end{array}$ \\
\hline Part (ii) & 0 & $\begin{array}{l}\text { No response; no improvement on 1. (Part } \\
\text { (i)) }\end{array}$ \\
\hline \multirow[t]{3}{*}{ 2. Data set/s to be used } & 1 & $\begin{array}{l}\text { One of data set, measurement or time } \\
\text { related to refined question } 1 .\end{array}$ \\
\hline & 2 & $\begin{array}{l}\text { Two of data set, measurement or time } \\
\text { related to refined question } 1 .\end{array}$ \\
\hline & 3 & $\begin{array}{l}\text { Names data set and measurement over time } \\
\text { period - related to refined question } 1 .\end{array}$ \\
\hline Part (ii) & 0 & No response; unlabelled plot \\
\hline 3. Analyse data & 1 & $\begin{array}{ll}\text { Plot with attempted } & \text { but } \\
\text { inadequate/inappropriate labels } & \text { (as } \\
\text { requested in the question) } & \\
\end{array}$ \\
\hline \multirow{2}{*}{$\begin{array}{l}\text { Remember, part of analysing the } \\
\text { data is to plot and organise the } \\
\text { data. This gives us a good }\end{array}$} & 2 & $\begin{array}{l}\text { Plot labelled adequately/appropriately (as } \\
\text { requested) but no data }\end{array}$ \\
\hline & 3 & Appropriate labels and minimal data \\
\hline
\end{tabular}




\begin{tabular}{|c|c|c|}
\hline Question & Code & Description response \\
\hline $\begin{array}{l}\text { understanding of the "whole } \\
\text { picture." Use the space below to } \\
\text { sketch your graph, ensuring you: } \\
\text { label your axis, record your end } \\
\text { points, record your scale. }\end{array}$ & 4 & $\begin{array}{l}\text { Appropriate labels on plot as required and } \\
\text { meaningful data related to refined question } \\
1 \text {. }\end{array}$ \\
\hline Question & Code & Description response \\
\hline Part (iii) & 0 & No response \\
\hline \multirow{2}{*}{$\begin{array}{l}\text { [from representation in } \\
\text { TinkerPlots] }\end{array}$} & 1 & One accurate observation \\
\hline & 2 & Two accurate observations \\
\hline $\begin{array}{l}\text { 1. What does your representation } \\
\text { tell you? List as many things as } \\
\text { you can see. }\end{array}$ & 3 & Three or more accurate observations \\
\hline Part (iii) & 0 & $\begin{array}{l}\text { No response; decision not related to } \\
\text { evidence }\end{array}$ \\
\hline \multirow{2}{*}{$\begin{array}{l}\text { 2. From your analysis, what } \\
\text { decision/conclusion have you } \\
\text { reached? }\end{array}$} & 1 & General relevant comment on data \\
\hline & 2 & $\begin{array}{l}\text { Specific comment including details of } \\
\text { sport, time, improvement, etc. }\end{array}$ \\
\hline Part (iii) & 0 & $\begin{array}{llll}\text { No } & \text { response; } & \text { statement } & \text { without } \\
\text { justification } & & \\
\end{array}$ \\
\hline \multirow[t]{2}{*}{$\begin{array}{l}\text { 3. How certain of your conclusion } \\
\text { are you? Explain your answer. }\end{array}$} & 1 & $\begin{array}{l}\text { Certainty based on general claim of } \\
\text { "evidence" }\end{array}$ \\
\hline & 2 & Certainty based on specific "evidence" \\
\hline Part (iv) & 0 & $\begin{array}{l}\text { No response; "Yes" or "No" with no } \\
\text { explanation }\end{array}$ \\
\hline 1. Reflect on your decision & 1 & $\begin{array}{l}\text { "Yes" or "No"; with brief superficial } \\
\text { reasoning }\end{array}$ \\
\hline \multirow[b]{2}{*}{$\begin{array}{l}\text { Reflecting on the TED article, } \\
\text { would you change your } \\
\text { conclusion? Slightly? A lot? If so, } \\
\text { write your new conclusion below. } \\
\text { If not, record your reasons below } \\
\text { why you feel your previous } \\
\text { conclusion is still justifiable. }\end{array}$} & 2 & "Yes" or "No"; with specific reasoning \\
\hline & 3 & $\begin{array}{l}\text { Unsure; with reasoning for both "Yes" and } \\
\text { "No" }\end{array}$ \\
\hline Part (iv) & 0 & $\begin{array}{lll}\text { No response; comment } & \text { without } \\
\text { explanation }\end{array}$ \\
\hline \multirow[t]{2}{*}{ 2. How certain of your conclusion } & 1 & Very certain because of evidence \\
\hline & 2 & Not very certain because of TED \\
\hline
\end{tabular}




\section{ACCEPTED MANUSCRIPT}

\begin{tabular}{|l|l|l|}
\hline Question & Code & Description response \\
\hline are you now? Explain your answer. & 3 & $\begin{array}{l}\text { Not certain - times improved but maybe } \\
\text { because of non-human factors }\end{array}$ \\
\hline
\end{tabular}




\section{ACCEPTED MANUSCRIPT}

Table 1. Questions from the student workbook.

\begin{tabular}{|c|c|}
\hline $\begin{array}{l}\text { Research } \\
\text { Question }\end{array}$ & Questions from the corresponding part of the student workbook \\
\hline \multirow{3}{*}{ Part (i) } & 1. Pose a question \\
\hline & 2. Collect data \\
\hline & What data would you need to answer your question? \\
\hline \multirow[b]{4}{*}{ Part (ii) } & 1. Refined group question [for chosen data set/s] \\
\hline & 2. Data set/s to be used \\
\hline & 3. Analyse data \\
\hline & $\begin{array}{l}\text { Remember, part of analysing the data is to plot and organise the data. } \\
\text { This gives us a good understanding of the "whole picture." Use the } \\
\text { space below to sketch your graph, ensuring you: label your axis, } \\
\text { record your end points, record your scale. }\end{array}$ \\
\hline \multirow{4}{*}{ Part (iii) } & [From representation in TinkerPlots] \\
\hline & $\begin{array}{l}\text { 1. What does your representation tell you? List as many things as you } \\
\text { can see. }\end{array}$ \\
\hline & 2. From your analysis, what decision/conclusion have you reached? \\
\hline & 3. How certain of your conclusion are you? Explain your answer. \\
\hline \multirow{3}{*}{ Part (iv) } & 1. Reflect on your decision \\
\hline & $\begin{array}{l}\text { Reflecting on the TED article, would you change your conclusion? } \\
\text { Slightly? A lot? If so, write your new conclusion below. If not, record } \\
\text { your reasons below why you feel your previous conclusion is still } \\
\text { justifiable. }\end{array}$ \\
\hline & 2. How certain of your conclusion are you now? Explain your answer. \\
\hline
\end{tabular}


Table 2. SOLO Levels for each part of the activity based on workbook responses.

\begin{tabular}{|c|c|c|}
\hline $\begin{array}{l}\text { SOLO } \\
\text { Level }\end{array}$ & $\begin{array}{l}\text { Rubric } \\
\text { score }\end{array}$ & Description of Level \\
\hline \multicolumn{3}{|c|}{ Part (i) - Initial question posed } \\
\hline Rel & 5 & $\begin{array}{l}\text { Specific mention of a sport, an appropriate type of improvement and } \\
\text { related data measurement, and time period }\end{array}$ \\
\hline Multi & 4 & Notes two elements relevant to the description of question and data \\
\hline Uni & $2-3$ & $\begin{array}{l}\text { Focuses on only one element of either posing the question or } \\
\text { suggesting data, or both }\end{array}$ \\
\hline \multicolumn{3}{|c|}{ Part (ii) - Refined question, data, and plot } \\
\hline Rel & $8-9$ & $\begin{array}{l}\text { Produces hand-drawn-plot with details as required fitting data selected } \\
\text { for the new refined question or misses one detail but includes all } \\
\text { elements in other questions }\end{array}$ \\
\hline Multi & $6-7$ & $\begin{array}{l}\text { Inconsistent but puts together at least two elements on two of the } \\
\text { questions }\end{array}$ \\
\hline Uni & $3-5$ & $\begin{array}{l}\text { Struggles in places but recognises and notes at least some single } \\
\text { elements required across the questions }\end{array}$ \\
\hline \multicolumn{3}{|c|}{ Part (iii) - Using representation in TinkerPlots to reach conclusion } \\
\hline Rel & $6-7$ & $\begin{array}{l}\text { Both three or more accurate observations from TinkerPlots and at least } \\
\text { one of decision and certainty based on specific evidence from } \\
\text { elements }\end{array}$ \\
\hline Multi & 5 & $\begin{array}{l}\text { Giving two or fewer observations and conclusion or certainty based on } \\
\text { a non-specific claim of evidence from elements }\end{array}$ \\
\hline Uni & $2-4$ & $\begin{array}{l}\text { Inconsistent across observations from TinkerPlots and use of evidence } \\
\text { from elements in decision and certainty in conclusion }\end{array}$ \\
\hline \multicolumn{3}{|c|}{ Part (iv) - Further information } \\
\hline Rel & $5-6$ & $\begin{array}{l}\text { Expresses uncertainty with specific or multiple reasons associated } \\
\text { with evidence from elements }\end{array}$ \\
\hline Multi & $3-4$ & $\begin{array}{l}\text { At least one reason from elements including specific reasoning for } \\
\text { decision and/or reference to TED for certainty }\end{array}$ \\
\hline Uni & $1-2$ & $\begin{array}{l}\text { Responds with superficial reasoning and/or strong certainty on } \\
\text { decision without evidence from elements }\end{array}$ \\
\hline
\end{tabular}




\section{ACCEPTED MANUSCRIPT}

Table 3. Response for initial problem posing.

\begin{tabular}{|c|c|c|c|}
\hline $\begin{array}{l}\text { Level } \\
\%\end{array}$ & Pose a question & What data would you need? & \\
\hline \multirow[t]{2}{*}{$\begin{array}{l}\text { Rel } \\
30 \%\end{array}$} & $\begin{array}{l}\text { Are } 100 \mathrm{~m} \text { sprinters getting faster } \\
\text { over the last } 20 \text { years? }\end{array}$ & $\begin{array}{l}\text { We need a source to world records } \\
\text { for } 100 \mathrm{~m} \text { going back over } 20 \\
\text { years. We could get info from } \\
\text { books, films, websites and } \\
\text { newspapers. }\end{array}$ & [ID038] \\
\hline & $\begin{array}{l}\text { Are young male sprinters getting } \\
\text { faster over a period of four years? }\end{array}$ & $\begin{array}{l}\text { Running speed times of young } \\
\text { male sprinters in } 2008 \text { and } 2012 \\
\text { olympics on } 100 \text { m runs. }\end{array}$ & [ID099] \\
\hline \multirow[t]{2}{*}{$\begin{array}{l}\text { Multi } \\
31 \%\end{array}$} & $\begin{array}{l}\text { Are sprinters getting faster over a } \\
\text { period of time? }\end{array}$ & $\begin{array}{l}\text { Running speed times of sprinters } \\
\text { over a period of time. }\end{array}$ & [ID127] \\
\hline & $\begin{array}{l}\text { Are swimmers getting faster every } \\
\text { swimming training? }\end{array}$ & $\begin{array}{l}\text { The previous time and the latest } \\
\text { time. }\end{array}$ & [ID047] \\
\hline \multirow[t]{2}{*}{$\begin{array}{l}\text { Uni } \\
38 \%\end{array}$} & $\begin{array}{l}\text { Are people who play sport, } \\
\text { improving over time? }\end{array}$ & $\begin{array}{l}\text { Olympic sport records over the } \\
\text { time frame of } 20 \text { years ( } 9 \text { olympic } \\
\text { games). }\end{array}$ & [ID009] \\
\hline & $\begin{array}{l}\text { Are athletes getting faster over } \\
\text { time. }\end{array}$ & $\begin{array}{l}\text { A data display of all the fastest } \\
\text { runners now and look at there } \\
\text { [their] older records. }\end{array}$ & [ID005] \\
\hline
\end{tabular}




\section{ACCEPTED MANUSCRIPT}

Table 4. Responses for refining questions, data, and plot.

\begin{tabular}{|c|c|c|c|c|}
\hline $\begin{array}{l}\text { Level } \\
\%\end{array}$ & Refined question & Data to be used & $\begin{array}{l}\text { Plot created to analyse } \\
\text { data }\end{array}$ & \\
\hline \multirow[t]{2}{*}{$\begin{array}{l}\text { Rel } \\
45 \%\end{array}$} & $\begin{array}{l}\text { Are American Gold } \\
\text { medal winning male } \\
\text { runners, who sprint } \\
100 \text { metres between } \\
\text { the age of } 20-25 \\
\text { improving their speed } \\
\text { at the Olympics? }\end{array}$ & $\begin{array}{l}\text { The data sets to be } \\
\text { used: Age - } 20-25 \text {. } \\
\text { Olympic games year. } \\
\text { Gold medalists. Male } \\
\text { 100m sprinters. Time } \\
\text { results. Country - } \\
\text { USA. }\end{array}$ & 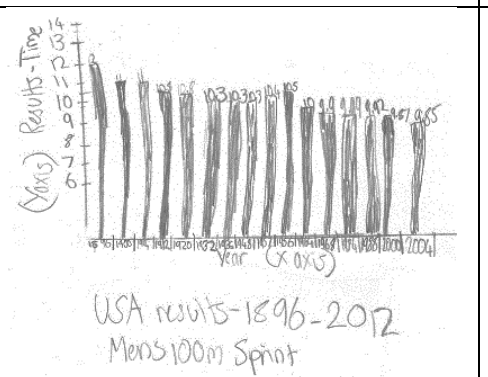 & [ID077] \\
\hline & $\begin{array}{l}\text { Have the men } \\
\text { competing in } 1500 \mathrm{~m} \\
\text { freestyle in the } \\
\text { olympic games that } \\
\text { won gold improving } \\
\text { over the years. }\end{array}$ & $\begin{array}{l}\text { The time and year of } \\
\text { each winner. }\end{array}$ & 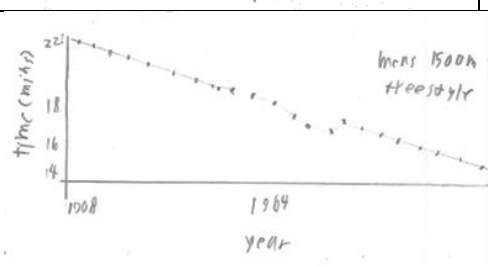 & [ID053] \\
\hline \multirow[t]{2}{*}{$\begin{array}{l}\text { Multi } \\
36 \%\end{array}$} & $\begin{array}{l}\text { Are sprinters getting } \\
\text { less times/every } 4 \\
\text { years every olympics } \\
\text { for mens } 100 \mathrm{~m} \text { sprint } \\
\text { gold medests } \\
\text { [medalists]. }\end{array}$ & $\begin{array}{l}\text { We are using mens } \\
100 \mathrm{~m} \text { sprint gold } \\
\text { medeals [medals] } \\
\text { recordeds [recorded] } \\
\text { in diff[e]rent olympics } \\
\text { to see if they're } \\
\text { getting better every } 4 \\
\text { yrs/every olympic. }\end{array}$ & Timesces: & [ID021] \\
\hline & $\begin{array}{l}\text { Are female } 100 \mathrm{~m} \\
\text { freestyle } 100 \mathrm{~m} \\
\text { swimmers getting } \\
\text { better every } 4 \text { yrs? }\end{array}$ & $\begin{array}{l}\text { Times of womens } \\
\text { olympic winners } \\
\text { every } 4 \text { yrs. }\end{array}$ & 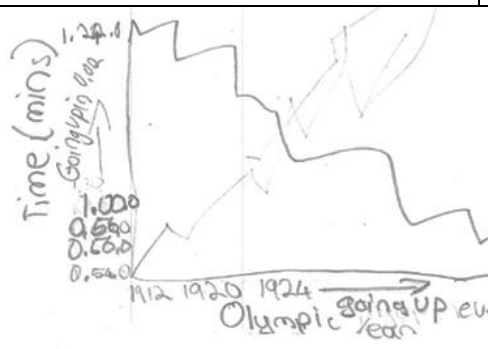 & [ID052] \\
\hline $\begin{array}{l}\text { Uni } \\
16 \%\end{array}$ & $\begin{array}{l}\text { In the olympic } \\
\text { games, are women } \\
\text { who compete in } \\
100 \mathrm{~m} \text { freestyle } \\
\text { improving every } \\
\text { olympic games? }\end{array}$ & $\begin{array}{l}\text { Women's } 100 \mathrm{~m} \\
\text { freestyle olympic } \\
\text { medal gold results. } \\
\text { Women's results. }\end{array}$ & 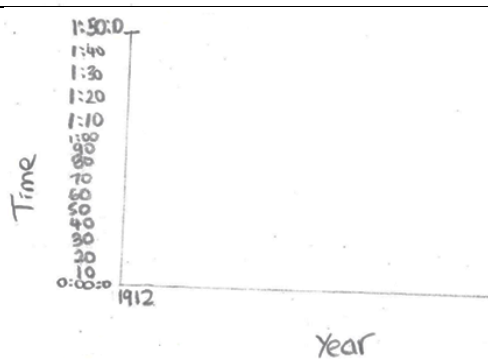 & [ID043] \\
\hline
\end{tabular}




\section{ACCEPTED MANUSCRIPT}

\begin{tabular}{|l|l|l|l|}
\hline Is the younger & Age and the time (15, & [ID089] \\
Swimmer better than & $17,18,20,22,23,24$, \\
the old swimmer? & $25,26,29) 10,20,30$, \\
& 40,50, times $1: 10$, \\
& $1: 20,1: 30,1: 40,1: 50$. & \\
& & & \\
& & & \\
\end{tabular}




\section{ACCEPTED MANUSCRIPT}

Table 5. Responses for analysis using plots created in TinkerPlots.

\begin{tabular}{|c|c|c|c|c|c|}
\hline $\begin{array}{l}\text { Level } \\
\%\end{array}$ & Plot & Plot tells? & Decision? & Certainty? & \\
\hline \multirow[t]{2}{*}{$\begin{array}{l}\text { Rel } \\
47 \%\end{array}$} & $\begin{array}{l}\text { sing } \\
\text { The trend in our plot's high jump results are increasing } \\
\text { gradually each time the Olympics take place. }\end{array}$ & $\begin{array}{l}\text { The graph's shape is } \\
\text { visable [visible] and it } \\
\text { shows the results } \\
\text { increasing. The results are } \\
\text { clustered around } 1948 \text { to } \\
\text { 2012. There's a gap } \\
\text { between } 1938 \text { to } 1948 \text {. } \\
\text { The scale is going up in } \\
\text { decades (x axis). The Y } \\
\text { axis scale starts at } 1.68 \\
\text { and is going up in } 0.24 \text {. }\end{array}$ & $\begin{array}{l}\text { In conclusion, } \\
\text { over the years } \\
1928 \text { to } 2012, \\
\text { the female high } \\
\text { jumpers have } \\
\text { improved. }\end{array}$ & $\begin{array}{l}\text { We are } 99 \% \\
\text { certain there } \\
\text { was an } \\
\text { increase in the } \\
\text { data collected } \\
\text { but we are not } \\
\text { certain this } \\
\text { data is } \\
\text { reliable. }\end{array}$ & [ID058] \\
\hline & $\begin{array}{l}\text { the plot shows the time of olympic gold medalists } \\
\text { men's } 1500 \mathrm{~m} \text { freestyle. it also show an overall } \\
\text { improvent in their times each time. }\end{array}$ & $\begin{array}{l}\text { Our representation } \\
\text { showed a continuous line, } \\
\text { with some cases not going } \\
\text { in the direction of the line, } \\
\text { in the general direction of } \\
\text { less time, this means you } \\
\text { can expect that the gold } \\
\text { medalist will probably } \\
\text { beat the time of the } \\
\text { previous winner. }\end{array}$ & $\begin{array}{l}\text { That you can } \\
\text { expect a record } \\
\text { in each } \\
\text { olympics, or at } \\
\text { least a better } \\
\text { time than the } \\
\text { previous gold } \\
\text { medalists. }\end{array}$ & $\begin{array}{l}\text { I am very } \\
\text { certain, since } \\
\text { the graph we } \\
\text { made was an } \\
\text { unmistakable } \\
\text { line, even } \\
\text { though some } \\
\text { cases broke } \\
\text { the pattern. }\end{array}$ & [ID053] \\
\hline \multirow[t]{2}{*}{$\begin{array}{l}\text { Multi } \\
34 \%\end{array}$} & 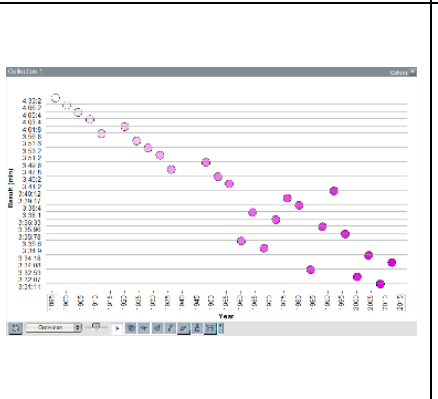 & $\begin{array}{l}\text { You can see the times are } \\
\text { decreasing over the years. } \\
\text { Since } 1956 \text { to } 2012 \text { the } \\
\text { data is very scattered. }\end{array}$ & $\begin{array}{l}\text { Throughout the } \\
\text { task myself and } \\
\text { my partner have } \\
\text { come to a } \\
\text { conclusion and } \\
\text { have found out } \\
\text { that over } 5 \text { years } \\
\text { of training the } \\
\text { men's Olympic } \\
1500 \text { m times } \\
\text { have improved. }\end{array}$ & $\begin{array}{l}\text { My } \\
\text { conclusion is } \\
\text { certain. The } \\
\text { data we have } \\
\text { collected. }\end{array}$ & [ID041] \\
\hline & $\begin{array}{l}\text { The line decends in a clear downward direction.lt tells } \\
\text { us that over time the swimmers definately improved. }\end{array}$ & $\begin{array}{l}\text { That our time swimmers } \\
\text { are becoming faster. The } \\
\text { times get better, } \\
\text { considerably because } \\
\text { there is an } 8 \text { minute gap } \\
\text { between } 1908-2012 \text {. The } \\
\text { range is from } 22: 48: 4 \text { to } \\
\text { 14:31:02. Between each } \\
\text { olympics the gaps } \\
\text { between each year have } \\
\text { been under a minute. }\end{array}$ & $\begin{array}{l}\text { That as time } \\
\text { continues every } \\
\text { four years the } \\
\text { times will } \\
\text { definitely } \\
\text { improve, } \\
\text { especially in the } \\
\text { next decade or } \\
\text { century. }\end{array}$ & $\begin{array}{l}\text { I'm very } \\
\text { confident in } \\
\text { my } \\
\text { conclusion, } \\
\text { because the } \\
\text { numbers don't } \\
\text { lie. }\end{array}$ & [ID048] \\
\hline $\begin{array}{l}\text { Uni } \\
19 \%\end{array}$ & 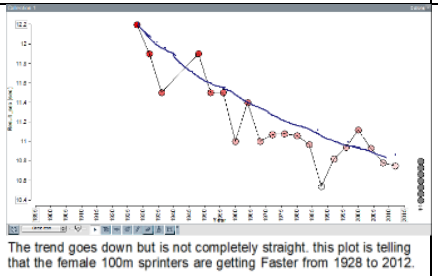 & $\begin{array}{l}\text { That the times get quicker } \\
\text { as we look to more recent } \\
\text { races than the ones in the } \\
\text { past. }\end{array}$ & $\begin{array}{l}\text { Over time, } \\
\text { female athelets } \\
\text { [athletes] have } \\
\text { gotten better at } \\
\text { the } 100 \mathrm{~m} \text { sprint. }\end{array}$ & $\begin{array}{l}\text { I am certain } \\
\text { that atheletes } \\
\text { [athletes] are } \\
\text { getting better. } \\
\text { The results } \\
\text { say so! }\end{array}$ & [ID059] \\
\hline
\end{tabular}




\section{ACCEPTED MANUSCRIPT}

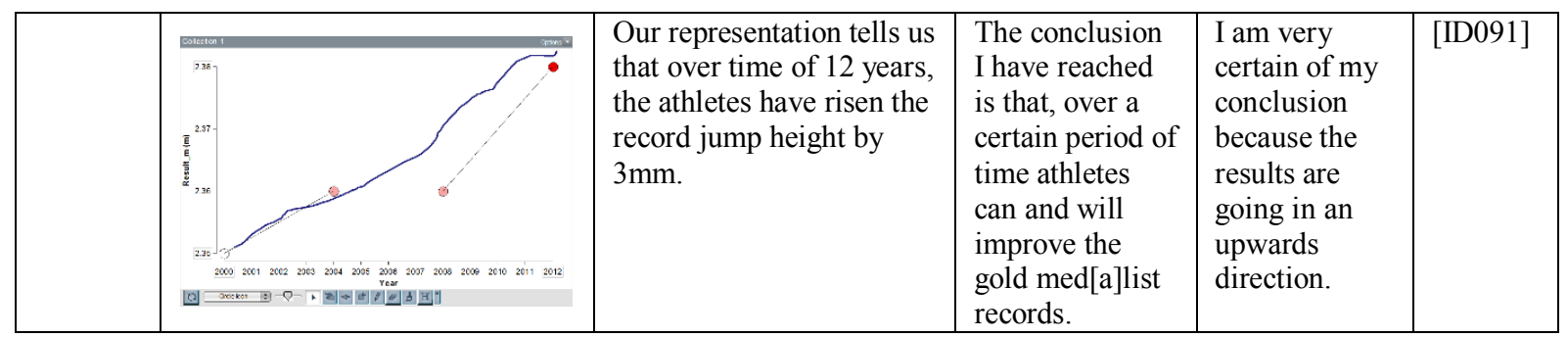




\section{ACCEPTED MANUSCRIPT}

Table 6. Responses for reflecting on further information.

\begin{tabular}{|c|c|c|c|}
\hline $\begin{array}{l}\text { Level } \\
\%\end{array}$ & Reflection & Certainty & \\
\hline \multirow[t]{2}{*}{$\begin{array}{l}\text { Rel } \\
25 \%\end{array}$} & $\begin{array}{l}\text { The TED article changed my mind, I } \\
\text { do not think athletes have improved a } \\
\text { lot since in the past the ground was out } \\
\text { of cinders unlike now, though some } \\
\text { athletes ran on the same ground } \\
\text { surface and have improved. }\end{array}$ & $\begin{array}{l}\text { I am not very certain since we will not } \\
\text { know how fast the athletes who ran on } \\
\text { cinder would have been if they ran on } \\
\text { the same ground as the other athletes. }\end{array}$ & [ID068] \\
\hline & $\begin{array}{l}\text { I would only change my conclusion } \\
\text { slightly - conclusion - I have reached } \\
\text { the conclusion that over time people } \\
\text { improved the h[e]ight of their jump } \\
\text { because of the new technology. Even } \\
\text { though people these days would've } \\
\text { probably beaten the other people (in } \\
\text { the olden days), the people generations } \\
\text { before would've still had a chance of } \\
\text { doing a better job if the technology had } \\
\text { improved. }\end{array}$ & $\begin{array}{l}\text { I am more certain of my new } \\
\text { conclusion than my old conclusion. } \\
\text { This is because after I read the TED } \\
\text { talk and all the things that have } \\
\text { scientifically proven, the opinion of } \\
\text { my conclusion before was slightly } \\
\text { needing a change. }\end{array}$ & [ID037] \\
\hline \multirow[t]{2}{*}{$\begin{array}{l}\text { Multi } \\
45 \%\end{array}$} & $\begin{array}{l}\text { I feel that we could change our } \\
\text { conclusion because we know that our } \\
\text { technology today has advanced our } \\
\text { sports such as gutters to stop ripples } \\
\text { and full suits. }\end{array}$ & $\begin{array}{l}\text { I am not as sure with my conclusion } \\
\text { because today we have a much bigger } \\
\text { advantage. }\end{array}$ & [ID076] \\
\hline & $\begin{array}{l}\text { I believe that sprinters are improving } \\
\text { however it should be noted that today } \\
\text { conditions are better for running back } \\
\text { then. }\end{array}$ & $\begin{array}{l}\text { I am not as certain as before, as new } \\
\text { factors have been brought to light and } \\
\text { therefore making me hesitate } \\
\text { somewhat. }\end{array}$ & [ID102] \\
\hline \multirow[t]{2}{*}{$\begin{array}{l}\text { Uni } \\
22 \%\end{array}$} & $\begin{array}{l}\text { After watching the TED article I am a } \\
\text { lot more certain that } 100 \mathrm{~m} \text { sprinters } \\
\text { have prossed [progressed] a lot since } \\
20 \text { years or so. }\end{array}$ & $\begin{array}{l}\text { I am very certain that over time } \\
\text { technology will help athletes become } \\
\text { stronger and faster. }\end{array}$ & [ID038] \\
\hline & $\begin{array}{l}\text { I would not change my answer because } \\
\text { the ted article is more about the new } \\
\text { technology whereas my investigation } \\
\text { question had nothing to do with } \\
\text { technology. }\end{array}$ & $\begin{array}{l}\text { Still the same because the TED article } \\
\text { did not make me any more certain } \\
\text { because it was irrelivant [irrelevant] to } \\
\text { my investigation question. }\end{array}$ & [ID066] \\
\hline
\end{tabular}




\section{ACCEPTED MANUSCRIPT}

Table 7. Summary of SOLO Levels.

\begin{tabular}{|l|l|l|l|l|}
\hline Level & $\begin{array}{l}\text { Part (i) } \\
\text { Initial } \\
\text { Posing }\end{array}$ & $\begin{array}{l}\text { Part (ii) } \\
\text { Refining }\end{array}$ & $\begin{array}{l}\text { Part (iii) } \\
\text { Decision }\end{array}$ & $\begin{array}{l}\text { Part } \\
\text { Reflecting }^{1}\end{array}$ \\
\hline Relational & $30 \%$ & $45 \%$ & $47 \%$ & $25 \%$ \\
\hline Multistructural & $31 \%$ & $36 \%$ & $34 \%$ & $45 \%$ \\
\hline Unistructural & $38 \%$ & $16 \%$ & $19 \%$ & $22 \%$ \\
\hline
\end{tabular}

\footnotetext{
${ }^{1}$ Eight percent did not complete Part (iv).
} 


\section{ACCEPTED MANUSCRIPT}
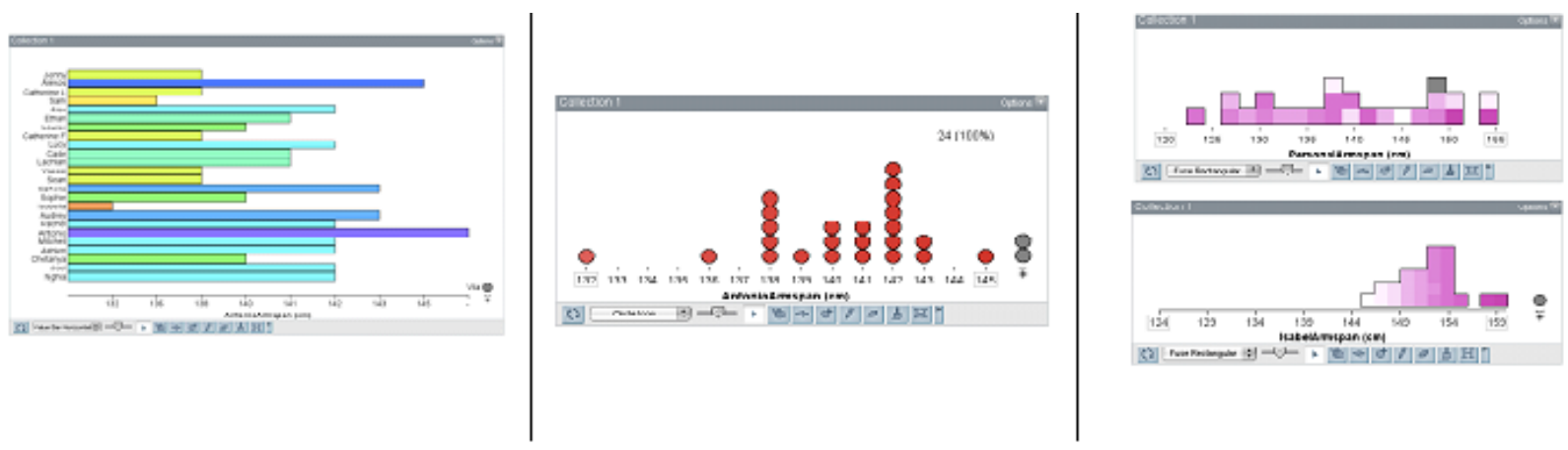

Figure 1. TinkerPlots plots created by students in Grade 4 (Watson \& English, 2013). 


\section{ACCEPTED MANUSCRIPT}

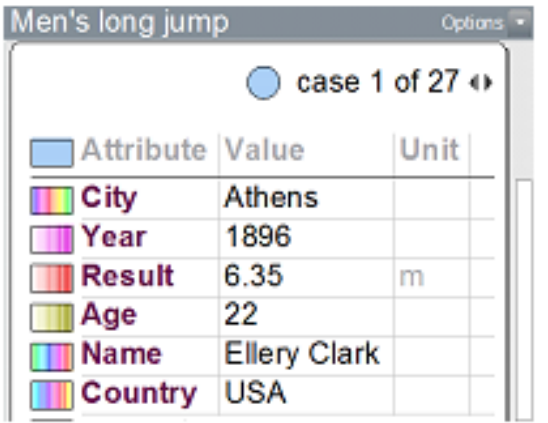

Figure 2. Data Cards for Men's Long Jump. 


\section{ACCEPTED MANUSCRIPT}

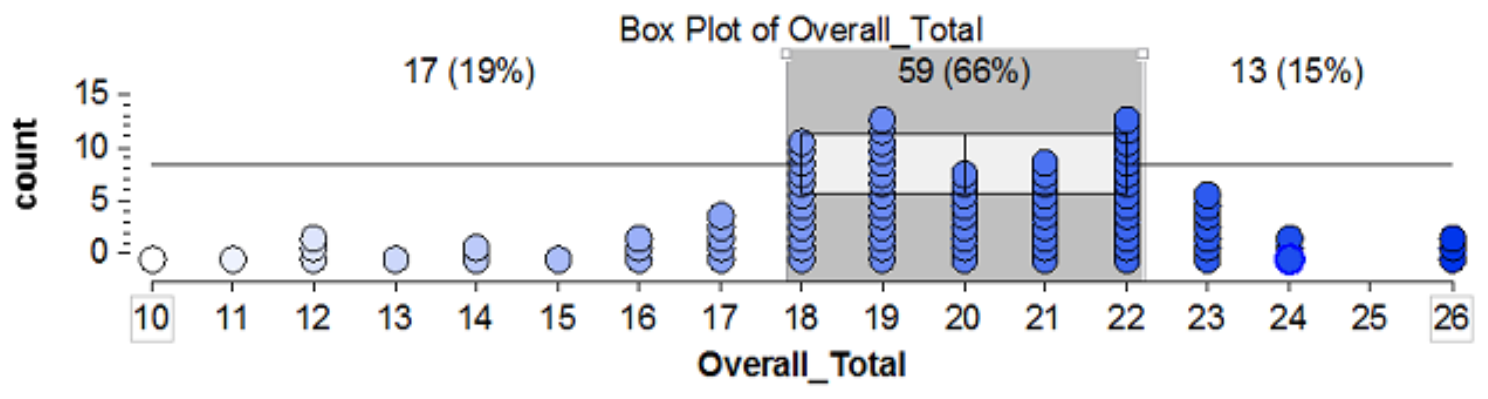

Figure 3. Overall total workbook scores for students $(n=89)$. 